\title{
Old English Power Structure in the Warlike Nature in Riddles no. 3, no, 29, no. 50 from the Exeter Book
}

\section{Struktur Kekuasaan Inggris Kuno dalam Imaji Alam yang berkenaan dengan Perang dalam Teka-teki no. 3, no. 29, no. 50 dari the Exeter Book}

\author{
Herditya Wahyu Widodo* \\ Universitas Negeri Malang, Jl. Semarang No. 5 Malang, Jawa Timur, Indonesia \\ *Penulis korespondensi, Surel: herditya.widodo.fs@um.ac.id
}

Paper received: 01-04-2021; revised: 15-04-2021; accepted: 30-04-2021

\begin{abstract}
This study focuses on Old English nature-themed riddle texts from the Exeter Book, analyzing the natural imageries that are significant in investigating how the literary content of Old English riddles, as accepted forms of poetry, reveals the Anglo-Saxon culture of their original authors. I focus on the power structure in Anglo-Saxon society revealed in the riddles, by analyzing the topic of warlike nature in them, focusing on the riddles no. 3, "Storm", no. 29 "Sun and Moon," and no. 50, "Fire." Natural experience described in these riddles is rendered by the Anglo-Saxons to reflect power hierarchy between male and female, servant and master, and human with God. The Anglo-Saxon riddles identify and assign the potent warlike attributes and actions of nature, and assign them to the more powerful factions (God, Master, Male) over the weaker factions (Humans, Servants, Female). This is done by the authors as an acceptable cultural interpretation of these natural phenomena, put in the riddles to make it possible for the riddles' intended Anglo-Saxon audience as clues to arrive at a culturally agreeable answer.
\end{abstract}

Keywords: old English, old English riddles, natural imagery, old English poetry, war imagery

\begin{abstract}
Abstrak
Studi ini berfokus pada teks teka-teki (Riddles) Inggris Kuno (Old English) bertema alam dari the Exeter Book, dengan menganalisa imaji alam yang signifikan, untuk mengetahui bagaimana teka-teki Inggris Kuno, sebagai salah satu karya sastra berbentuk puisi, mengungkapkan budaya Anglo-Saxon dari penulis aslinya. Saya berfokus pada struktur kekuasaan (power structure) dalam masyarakat Anglo-Saxon yang terungkap dalam teks teka-teki, dengan menganalisis topik sifat suka perang di pada teka-teki no. 3, "Badai", no. 29 "Matahari dan Bulan," dan no. 50, "Api." Pengalaman hidup mengenai alam digambarkan dalam teka-teki ini oleh para penulis Anglo-Saxon dengan mencerminkan hierarki kekuasaan antara laki-laki dan perempuan, hamba dan tuan, dan manusia dengan Tuhan. Teka-teki Anglo-Saxon mengidentifikasi dan menetapkan atribut dan tindakan alam yang suka berperang (warlike) kepada faksi yang lebih kuat (Dewa, Tuan, Laki-Laki) di atas faksi yang lebih lemah (Manusia, Pelayan, Wanita). Hal ini dilakukan oleh para penulis sebagai interpretasi budaya atas fenomena alam yang mereka lihat, dan dimasukkan ke dalam teka-teki untuk memungkinkan pembaca Anglo-Saxon sebagai petunjuk untuk sampai pada jawaban yang dapat diterima secara budaya.
\end{abstract}

Kata kunci: old English, Inggris kuno, teka-teki Inggris kuno, imaji alam, puisi Inggris kuno, imaji perang

\section{Introduction}

Scholarly investigations on Old English riddles from the Exeter Book mainly have been focusing on discovering viable solutions for the riddles, without giving the main focus on the 
content of the riddles as poetic texts that may reveal the Anglos Saxon culture of their original authors. As such, this study intends to focus on the content of the Old English riddle texts, analyzing natural imageries that are significant to some of these riddles. The aim is to investigate how Old English riddles reveal the power structure in Anglo-Saxon society by analyzing the riddles' topic of warlike nature ${ }^{1}$, focusing on the riddles no. 3, "Storm", no. 29 "Sun and Moon," and no. 50, "Fire."

Exploration on the topic of nature in the Old English riddles, compared to Old English poems, however, has been scarce and fragmentary. The scholars' neglect of the poetic qualities of the riddles may imply an incorrect belief that all riddles are only meant as simple verses made for light amusement, and as such, the riddles may not contain any deeper content and quality of other, longer and better Old English poems. Scholars, however, believe that some Old English riddles do have higher quality comparable to that of 'literary' Old English poems. Paull F. Baum, in the preface to his book, noted that some Old English riddles are well-written and contain very learned material (Baum, 1963). Kevin Crossley-Holland (1970) believes that riddles are created by poets, and that the riddles themselves are worthy poems that repackage the knowledge of common, familiar items into unusual objects of wonder. Ann Harleman Stewart (1975) also believes that riddles should mainly be understood as poems, taking its depth of meaning, content, and style into consideration. Referring to the riddles' poetic quality, Niles (2006, p. 23) hints at how even the simpler 'folk' riddles have the ability to capture the bigger picture of human culture and experience, by saying that 'the performance and interaction between the riddle poser and the solver can invoke a "human context" which is the subject of study of folklorists and anthropologists.

The question that needs to be answered, then, is whether the texts of the riddles, by themselves, contain any clues on Anglo-Saxon culture. As stated before, previous studies mainly search for solutions for Anglo Saxon riddles, and such studies do touch on socio-cultural aspect of Anglo-Saxon life. Studies on Old English riddles require gaining larger, more contextual socio-cultural knowledge of the intended Anglo-Saxon audience. This is done to understand how the riddles function in their intended Anglo-Saxon socio-cultural context and function. Although the exact socio-cultural function of Old English riddles is hard to pinpoint (Niles, 2006), Anglo-Saxon riddles are indeed meant to function within social interaction. This is because riddles, by their nature, require social interaction between the poser and the solver (Niles, 2006). Related to this, Kevin Crossley-Holland tells how Old English riddles were possibly meant to be read in a "smoky mead hall" (1970, p. 11). Heide Estes (2017) even goes so far that the riddles transmit ideas, ideologies, and cultural assumptions. These understandings point at the socio-cultural, even ideological functions of the Old English riddles, as a form of poetic entertainment that engages their audience. For a riddle to work in such a way, riddle makers must make sure that the riddles can be understood and solved by their Anglo-Saxon audience. Anglo-Saxon riddles must put recognizable clues based on shared common knowledge of Anglo-Saxon culture and society, delivered in a carefully constructed poetic riddle-form. In this way, the riddles as a text must have contained clues and knowledge of the Anglo-Saxon culture and society.

\footnotetext{
1 I would note that I focus here on the literary analysis on the riddles and not too much on the translation process. Therefore, I mainly analyze authoritative translations of the riddles by Crossley-Holland (1970) and accept his solutions to them. I only look at variant translations of specific keywords when it is significant enough to look for possible alternate meanings, notably from McGillivray's Reader (2011).
} 
Within this Anglo-Saxon cultural depiction of the riddles, the topic of nature is chosen. The topic of nature is a topic common in studies of Old English poems, and similarly, in this study, the topic of nature is discussed to reveal the connection between the riddles and old English poems, with the aim of drawing a larger picture of the structure of power in AngloSaxon culture. In Old English poems, such as Beowulf, Wife's Lament or Judith, scholars have similarly revealed how certain human traits are projected to nature. Craig Williamson (1977, p. 25) has indicated how certain words in Old English riddles have projected imaginative personification on certain objects, hinting at the warlike imagery of nature by Old English identification of the wind as "a warring servant". Investigating the theme of nature in the epic poem Beowulf, Ervene Gulley (1970) finds that the Anglo-Saxons' mood or emotional state is projected into nature, and nature is mostly described as grim, dangerous, and hostile. Gulley (1970) has come to the conclusion that Anglo-Saxons' life experience is related to, even bound by, the natural, physical world, while at the same time, nature is reduced only to the same level of Anglo-Saxons' experience.

Thus, in a similar way, Anglo-Saxon natural experience in the riddles can be considered as observations of nature translated by Anglo-Saxon culture and captioned by human experience and emotions. Certain degree of similarity to Gulley's finding in Beowulf's natural representation is found on the riddles, in which the natural theme in the riddles is also a projection of human feeling stamped into nature. The riddles offer certain human admiration and passion to the natural setting, similar to what Gulley (1970, p. 30) describes as the imbuing of nature with the "grandeur of courage, fame, and wisdom".

\section{Method}

This study is done as literary criticism on Old English riddles from the Exeter Book, specifically riddles no. 3, "Storm", no. 29 "Sun and Moon," and no. 50, "Fire". In the discussion that follows, the interpretation of natural, warlike power of nature is done by first considering the meaning of specific words or lines from the original riddles. The meaning here is translated to modern English, using Crossley-Holland's (2009) authoritative translation, also considering the possible alternative meaning or nuances of key words, using Crossley-Holland's (2009) and McGillivray's (2011) interpretation of individual words. To supplement the translated works, two online dictionaries are used: An Anglo-Saxon Dictionary, by Joseph Bosworth and T. Northcote Toller (2021) of University of Pennsylvania for a literal Modern English translation of the Old English words, and Old English to Modern English Translator by Phil Barthram (2021) for reference aid to word roots, forms, and parts of speech of particular Old English words. Both the Old English and Modern English versions of these Riddles are provided in the Appendix section for reference.

The solutions to the riddles are also considered in drawing the interpretation, to get the best estimate of what the riddles mean. This is done by following the solutions offered by Crossley-Holland (2009), since the original texts of the Old English riddles do not contain any solution to the riddles.

Possible connection to similar imagery in other Old English poems, if any, is also considered as a point of reference in drawing the interpretation of the riddles. This is mainly done to get a better, more complete Anglo-Saxon socio-cultural context, for a better interpretation of how the riddles depict power structure in their depiction of natural phenomenon. 


\section{Findings and Discussion}

The most eminent theme of the topic of nature in the riddles is that nature has warlike aggressiveness and overwhelming destructive power. One gets the sense of the majestic wrath and power of nature through the riddle no. 3, "Storm", arguably the best-formed riddles in the Exeter book (Baum, 1963), and in riddle no. 50, "Fire." Williamson (1977), believing the solution 2 to riddle no. 3 as "Wind" rather than "Storm", relates how the natural force of "wind" here acts like a 'demonic scourge'. The solution for riddle no. 3 can either be "storm" or "wind," but both solutions reflect the inherent destructive power of nature.

The riddle "storm" shares the same characteristic of "fire", as a warlike force causing havoc and destruction both to humans and, in the case of the "storm", inciting nature to be violent as well. The storm is described as riling up the ocean, the sky and clouds into frenzied, combative fury $(\ln 17,35-6,45)$ that unleashes arrows and sharp weapons to humans and nature $(\ln 51,54)$.

Similar to the "Storm" riddle, in the "Fire" riddle, the creature can inflict harm, as it can be used as weapons between foes (ln 3-4). Such might of the 'fiery creature' can also be savagely unleashed against anyone who lets this "warrior" creature to become "too proud" (ln. 10).

There is the sense, however, that the destructive force of nature is withheld and imprisoned, and this reveals a power structure within the text. The "Storm" riddle starts by describing the "frustrated" "creature, being "condemned" and "cornered" inside a "dungeon" where Earth, its guardian, "sits on" its "back" (ln. 1-6). The "dungeon" is located under the "fertile fields" (ln. 3). A closer look at this reveals that there is a feminine power related to the theme of imprisonment of these horrible forces of nature.

In the "Storm" riddle, the translation of the word "genearwað" which Crossley-Holland (1970) translates as "corners" 3 is originally written in a present participle form, which may also mean: "confine, cramp, force in 4 ." Such nuances of meaning chosen of this word reflect the Anglo-Saxon understanding of the nature of "“storm": the natural power of storm is 'frustrated' because it is confined in a space too small, hidden under the façade of fertile greeneries. It is very interesting when the original Old English poem for "fertile land" was "bearm pone bradan", which literally can mean "bosom then (be) broad." Human attribute is here being impressed on the brewing storm or wind; the origin of the storm is understood to be the same as frustration compressed inside a dark, extended 'bosom.' The suppressed maddening emotion of Nature is created when it is confined within a female 'fertile' and 'pregnant' body.

\footnotetext{
2 The solution "Storm" has been put forward by most of the riddles' editors and translators, which are Kevin Crossley-Holland, W.S. Mackie, F. Dietrich, Moritz Trautmann, and Edmund Erlemann. On the other hand, Craig Williamson and Charles W. Kennedy choose "wind", while Erica von Erhardt-Siebold argues for "atmosphere," and Laurence Shook opts for "fire" (Williamson, 1977, p. 129-30). Williamson (1977) in his book also describes how some versions of the "Storm" riddle are printed into one long riddle or divided into shorter two or three parts (1977, pp. 128-35). The authoritative Crossley-Holland (1970) translation, the one I am analyzing here, is the $2^{\text {nd }}$ and $3^{\text {rd }}$ smaller parts joined together, starting from line 31 of the original, longer version of the riddle, until the last line (see Appendix).

${ }^{3}$ Line 1 - 2 Crossley-Holland (1970) translation: Sometimes my Lord corners me / then He imprisons me all that I am / under fertile fields - He frustrates me

4 In this paper I use Craig Williamson's small dictionary, in his book's appendix (2009), to find possible alternative translations, and the online version of the Old English Dictionary (https://www.oldenglishtranslator.co.uk and https://bosworthtoller.com/ ).
} 
In a similar way, in riddle 30 "Fire", fire is fettered by women (ln $4 \mathrm{~b})$, while it is appreciated by men (ln $8 \mathrm{~b})$. The "Fire" riddle describes 'the creature' as being fettered by female power regardless of its great might, while men seek succor from it (ln 4-5).

The interpretation of nature's pregnant female body harboring ill frustrations, and fire fettered by women, can be understood as either the female role of comforting or withholding, the 'fire' of male-appreciated aggressiveness and stormy emotions. The similar theme can be seen in the poems Beowulf and Wife's Lament. In Beowulf, the Danish Queen Wealpeow acts to bring peace between peoples, honoring her guests and securing the help of Beowulf (CrossleyHolland, 2009). Hildeburh, Freawaru and Queen Thryth, were women wed to the enemy to secure peace between conflicting groups (Crossley-Holland, 2009). Queen Thryth was called a 'peace-weaver' for being in such a role, and because she brings drinks and gives gifts to the warriors, in a role similar to Wealpeow. Similar to this, The Wife's Lament talks about a woman who kept peace with the aggressive, painful world. The wife, mistreated and abandoned, is described as nobly and passively accepts her forlorn fate (Niles, 2003). It is worth noting that this imagery in the poem is similar to the imagery of the verdant hill imprisoning the might of the fiery storm in the 'Storm' riddle.

The natural force of storm and the fire, however, can bring destruction to the world, if they are released out of control. The "storm" within the female 'bosom' of the green hills can only be controlled or set loose by its Lord, who is also the storm's capturer. This 'Lord' can then be seen as pointing towards the male power in control of the female's bottled emotions.

The fire in the riddle, however, can be set loose if it is not well taken care of, by "maiden and men" or let to be too "proud" (ln 5). The creature in the riddle "Fire" has several attributes matching that of human emotion of anger. 'Anger' can fulfill some of the clues' requirement: being a 'warrior' trait, being used as a weapon to inflict harm between foes (ln 3-4), bringing 'warmth' (ln 8), and savagely destroying the world if joined with pride - another human emotion, and, relating to the previous discussion, being 'fettered' by women, either as a peaceweaver or a comforter.

Another way of seeing this is that women hold the power over 'fire,' seeing how fire's power is fettered by women in the first place. The riddle can suggest that if set loose by its female guardian, the unchained "fire" can ravage the world, men, and nature. Similar examples of this riddle's interpretation of 'fire' can be seen in other Old English poems: The Wife's Lament and Judith.

In the case of the Wife's Lament, Barrie Ruth Straus (1981) has concluded that the forlorn Wife does not bottle up her frustration and passively accept her fate, as most scholars interpret her to be. Rather, Straus (1981) believes that she indeed acts upon her sufferings, turning her words into a powerful curse directed to the husband. Here, the Wife has unfettered her 'storm,' letting loose 'fire; to the parties that harmed her. Another existence of a woman guardian acting on 'fire', in similar way to the 'fire' riddle, can also be seen in another Old English poem, Judith.

The Old English poem Judith indicates such female "fire" when the female heroine murdered the drunk Holofernes. Ivan Herbison (2010) has discussed how the character Judith is presented not as a leader or warrior female, but rather a devout follower, a Christian nonwarrior heroine, whose warrior-like attribute and leadership power came from God, which results as her being rendered as a somewhat passive woman. Yet, there are certain 'fire' and 
warrior related imagery assigned to Judith, when she was about to kill an enemy in order to win a war - the action usually reserved to male warriors. Judith is described as a 'radiant', 'bright,' or 'shiny' maiden ${ }^{5}$, having a light-giving and fiery inner self as she describes her heart as being 'kindled' or 'inflamed' (onhæted), just before she decapitated Holofernes' ${ }^{6}$. Holofernes, letting his guard down under the influence of drunk and pride, was destroyed by Judith who kept her bravery and fiery determination firmly controlled in her heart.

It is worth noting here that Judith was never a warrior in the full sense, and she is only a follower of God, working through His whims. Similarly, the Wife in Wife's Lament can only curse in silence; she could not, and was not described as, openly confronting or contesting her husband's power. Therefore, the female is never meant to be the holder of power over male warriors, the wielders of 'fiery passion.' In this similar way, the riddle 'fire' makes an implicit statement in line 4-5: although women can fetter the strong 'fire,' they are never the real Master of It, as indicated that if they let fire become too 'proud', too large and uncontrolled, it will brutally savage them.

The riddle "fire", therefore, through its allusion to human strength and anger, advises its reader to be cautious of fire and fiery emotions, as both can bring "succor," "warmth,", bravery, and they can also fulfill the need of people, such as the case of Judith and the Jews, only if the fire is 'fettered' and hold in check. Otherwise, if the 'fire' or burning emotions are being proudly borne, such as in the case of the fiery passion and prideful Holofernes, they can also act as savage destroyers to their master. The imprisonment or control over natural forces thus teaches the wisdom: although they may bring benefit to men $(\ln 3)$ for the warmth "offered in return" (ln 8), they must be carefully 'kept' by men and maiden, because fire, as well as warlike, fiery emotion of anger, must not let to be uncontrolled, or be 'proud,' lest they can cause destruction to that person, and his society. The 'fire' in the riddle can act destructively, but also benevolently. However, this is not the case with the storm, which acted only destructively.

Unlike 'fire,' the storm in Old English riddle no. 3 is described as a loose, destructive force that serves no direct benefit to humans. This imagery serves as an appreciation to the magnificent power of the storm, but most importantly, serves as a reminder of the greatest power of God. In the riddle, the storm's warlike destructiveness has always been there, inert until it is released from its prison. There is a long description of its unstoppable destructive strength, launching other forces of nature against human fortifications. The storm directs a terrible force to shake "houses and halls" (ln 8-9), battling a ship full of screaming sailors (ln 25-6) by engaging it in a "savage battle" (ln 28). The storm screams "dins of destruction" that "echo above dwelling of men" (ln 39-41), causing terror (ln 33) that make human strongholds "succumb to dread" (ln 48-9). As such, the 'Storm' riddle can be interpreted as paying homage to the terrible battle-like prowess of the natural storm.

However, the riddle also suggest remembrance to the mightiest power in the riddle, that of the lord or God7. The riddle starts with it being in captivity of the "Lord" (ln 2-4). The 'storm' reveals its own nature in the last stanza: it is the "origin of all that strife" (ln 59), whose Lord

\footnotetext{
5 Line 14, ides ælfscinu: “elf-shining woman”; Line 43, torhtan mægð: “bright maiden”; Line 58, beorhtan idese: "bright lady"

6 Line 86-7a, Pearle ys me nu ða / heorte onhæted: “I am now severely (afflicted) / my heart is inflamed." My own literal translation using the online dictionaries as aid.

7 The original Old English word is frea, which may mean "lord, king, God; husband" (Bosworth \& Toller, 2021),

"master" (Barthram, 2021)
} 
renews its power (ln 66). It is a "mighty servant" of the Lord God that obeys His commands (ln 67). In contrast to riddle 'fire', whose keeper and 'maker' is human, the creator and master of 'storm' is not human but God. Humans in this riddle are weak and powerless before the might of the storm, and, in turn, the storm is powerless before the might of God. The storm, after revealing his unstoppable power in the preceding lines of the riddle, reminds the reader that there is a greater power than his: that of God. For example, there are moments when the storm asks the reader "Who can restrain me?" (ln 34). In the ending of the riddle, the storm requires that its existence must be joined to that of its Lord. Guessing the answer in the riddle, saying the name 'storm,' must be joined with saying the name of the Lord who 'restrain' and 'rouses' the storm (ln 73-5). The main point here, therefore, is remembrance of God.

In this riddle humans have absolutely no control over storm, and only God does. It is only by God's protection, then, that humans can ever hope to be protected from the terrible destruction of the storm. The riddle here makes the statement about the 'purpose' of storm's existence: to make humans to remember God, to turn to His mercy and protection. Storm, as a combative power of nature, is represented as unpredictable, savage, warlike, uncontrollable, and seemingly purposeless, but its wanton destructiveness, in the end, serves as a tool of remembrance of God. In the riddle, there seems to be no direct reward or compensation by the destruction of the natural storm. The only lesson is that people are always losing, and therefore, are expected to realize their weaknesses, and be patient. The realization of the self's weakness and the resulting patience and remembrance of God are the reward and lesson learned. The Anglo-Saxon's concept of God is therefore using warlike, invading nature, unleashed to make men understand their weak, insignificant position in nature, and then turn to remembrance and salvation from God, the ruler of storm.

In this interpretation, there is an appreciation of a top-down power hierarchy between God and humans, an appreciation of the holder of the greater power, be it God or otherwise. God, holder of power, can destroy and ravage men, by using the storm and nature as a tool, and men can only accept this fate. There is nothing that the weak men can do but to endure the savage, invading nature that engages them in a 'battle'. The power hierarchy here reminds weak humans to serve their higher Lord, which can mean serving God, or serving their 'leader,' since in the original riddle, the word "frea" for 'God' $(\ln 31,95)$ can also refer to a worldly lord or a master (Bosworth \& Toller, 2021). In reminding their readers that the men are insignificant, weak before their 'Lord,' whose name can also refer to their own worldly ruler, the riddle can be understood as implicitly encouraging people to follow obediently their rulers as well, enduring their incomprehensible punishment and savagery. There is an explicit lesson of obedience taught here, in the riddle conveying the message to its readers to submit completely to the figure of higher power, without any mentioning of rewards.

The riddle of the sun and moon, however, does not include any higher power that restrains these natural forces; instead, as the riddle 'fire' has hinted before, the 'sun and moon' riddle refers to the male domination over female. The riddle is structured as a narration which pays homage to the cycle of sun and moon, in which the sun and moon are depicted in contrasting parallels. The 'female 8 Moon is described as a "strange creature," like a "bright ship"

8 Crossley-Holland (1970) assigns the genders of the moon and the sun, which other translation does not do, such as the translation by Paull F. Baum (1963, p. 7). It is possible that Crossley-Holland refers to possible Old English words for the moon, the feminine "heofoncandel," "mone," or feminine noun "mónapfylen" ('time of the full moon') as the basis of his translation of moon's female gender. Possible masculine Old English word 
floating in the air, "bearing away plunder between her horns" from a "foray" (ln 1-4). She then cunningly protects her plunder in her stronghold (ln 5). Here the moon is like a pirate ship, and the reference to the horns can mean the horns on either end of the Viking ship, or that the plundering pirate ship is a she-beast. It is interesting to note too that the treasure is undescribed here, and one must wonder what kind of treasure that the moon has. After that, the riddle tells that a "mighty" creature, the sun which is 'familiar' to inhabitants of earth, seized the 'treasure' from the moon and drove the "wanderer" away (ln 7-9). There are contrasting parallels here that worth noting here: first, the male plunderer, sun, versus the female plunderer, moon; second, the recognizable, familiar sun versus the unfamiliar, strange, moon; and third, the mighty, marauding, active sun versus the passive, strange, frustrated moon.

The coupling of the female-gendered moon with inferior power, passiveness, and strangeness reflects the male-domination over women and the assigning proper warlike attributes to the male gender. The parallel construction, as Margaret Locherbie-Cameron (1992) has noted in her explanation of Old English poetic construction, reveals deeper meaning in the contrasting elements, in this riddle, between male and female. The warlike moon is considered as unnaturally hold the power of a warrior, as signified by her 'strangeness,' and 'horns,' while the 'mighty' sun is described as "familiar to all dwellers on earth" (ln 8).

One possible treasure that the moon has stolen is light. There is the Old English belief that the moon takes its 'light' from the sun (Williamson, 1977, p. 227), and this can be related to the 'light,' 'fire,' and 'anger' discussed previously. The sun is a fiery symbol, a significant lightgiver ${ }^{9}$, and it is implied in the previous riddle, that 'light' may point to 'fire' as well. Therefore, the moon can be seen as 'plundering' the sun's fire; an 'unusual' female 'plundering' an attribute reserved to male warriors. The female unnaturally wields treasure of plunder and the warlike attribute of marauding, but the riddle then states that she is to be put back into her 'appropriate' place as passive and non-resistant. The moon receives her punishment by being defeated by the mighty sun who is a popular figure of power, as indicated by him being "familiar to all dwellers on earth" (ln 8) She passively accepted, although bitterly, this defeat; she did not try to win back her plunder but went away quietly back to her hiding place.

In accepting her defeat, the female moon here is either neglecting or misusing her warlike attribute since the moon gained her treasure in the first place by plunder: she attacked to seize by force, others' treasure. Yet she became passive and weak when the male sun came and took the plunder away from her. The sun, described as "mighty" and "familiar to all that dwells on earth," took away what the "strange creature" - the moon - had plundered. It can be concluded here that the power hierarchy here is between superior, popular, male against the inferior, strange, female. The riddle put the context of nature in the confirmation of the male warlike sun's suppression of female moon, and the justification of such, by her defeat, and by her inability to resist or battle the marauding male sun. The wanderer, the moon, did not appear to battle or resist the sun in the riddle, instead it only harbored "hostility," and disappeared. It is worth noting that the female's harboring of hostilities here is similar to the

for the sun is "wuldor-gimm". However, other Old English word for moon, such as "mona" is masculine, and there is a feminine word for sun, "dæg-candel" (Barthram, 2021).

9 As signified in one possible word for sun in Old English, "dægcandel” (day-candle) (Bosworth \& Toller, 2021; Barthram, 2021). 
riddle 'storm', where the female's harboring of hostilities is depicted as the 'green fields' that are pregnant with hostile forces.

The 'sun and moon' riddle then concludes with a closure, that "dust lifted, dew fell" and that nobody knows where the moon, the "strange creature" goes to (ln 12-4). The sun and moon, both natural objects, are described as plunderers; both ascribe to marauding others' possessions. This, added to reference to the moon's "foray", "stronghold," the "mighty" sun and his seizure of the moon's treasure, suggest warlike imageries that the riddle imposes upon the natural objects of sun and moon. The naturalistic, calm closure can suggest an Old English consensus of interpretation of nature, the understanding of the natural cycle, order, or confirmation of plundering and counter plundering. Nature does not 'protest' against such a despicable act of a robber being robbed by another, mightier, robber. The impression is that in the natural world, by the natural law, a more powerful faction should take the treasure of the weaker one, and it is natural to do this by force. Coupled with the male-female, active-passive oppositions mentioned earlier, this imagery of sun and moon seems to reflect 'natural' justification to the act of women subjugated by men, and justification for powerful people plundering the weaker ones. The riddle signals acceptance and justification of the act of marauding and invading - perhaps an interesting justification made by the Anglo-Saxon, whom themselves had often been the victims of marauding Vikings.

\section{Conclusion}

The natural experience described in riddle 3, "storm"; riddle 50, "fire", and riddle 29, "sun and moon" are observations of nature that are rendered by the Anglo-Saxons to reflect power hierarchy between male and female, servant and master, and human with God. The Anglo-Saxon riddles also identify the aggressive properties of natural forces; the warlike attributes and actions are selected and assigned to the natural phenomenon to convey better interpretation of these natural phenomena, to make them more comprehensible and making more sense, to the riddles' Old English audience. The power relationship between servant and master is revealed in the riddle 3, "storm" also revealing the utmost power of God over insignificant, powerless humans. The riddle "storm" reveals that the powerful God, or a worldly ruler of men, can deliver punishment to his weaker subjects who are expected to learn to fear their rulers. This interpretation is also applicable to Riddle 50, "fire", which makes a similar statement of the superiority of the master, and the dire consequence when the servants are allowed to grow uncontrollable and prideful. In male-female aggression and power relationship, Riddle 29 assigns superiority of the male over female, in which mighty male Sun may take the strange female moon's plunder easily without repercussion. Riddle 3, "storm" can also be seen as ascribing the female with the seemingly neutralizing or peace-invoking qualities over aggression, while in riddle 29, "sun and moon," female's combative attribute is considered unusual, and it is defeated by the male, the accepted wielder of power and aggression. In the process of redefining, refocusing, and interpreting the attributes of these natural phenomena for use as riddle clues, nature's combative aspects are highlighted. This implies that such a description of warlike nature and power hierarchy is what the riddle poets considered to be the best, carefully selected interpretations that enable the retelling of these natural phenomena to be comprehensible and recognizable to their Anglo-Saxon audience.

\section{References}

Barthram, P. (2021). Old English to modern English translator. Retrieved from https://www.oldenglishtranslator.co.uk/index.htm 
Baum, P. F. (1963). Anglo-Saxon riddles of the Exeter book. Durham: Duke University Press.

Bosworth, J., \& Toller, T. N. (2021). Bosworth-Toller Anglo-Saxon dictionary: An Anglo-Saxon dictionary. Retrieved from https://bosworthtoller.com/

Crossley-Holland, K. (1970). Storm and other old English riddles. New York: Farrar, Straus \& Girrard.

Crossley-Holland, K. (2009). The Anglo-Saxon world: An anthology. New York: Oxford University Press.

Estes, H. (2017). Objects and hyperobjects. In Anglo-Saxon literary landscapes (pp. 145-176). Amsterdam: Amsterdam University Press. doi: 10.2307/j.ctt1zkjxx3.9

Gulley, E. (1970) The concept of nature in Beowulf. Thoth, 11(1), 16-30.

Herbison, I. (2010). Heroism and comic subversion in the old English Judith. English Studies, 91(1) 1-25.

Locherbie-Cameron, M. A. L. (1992). Anglo-Saxon attitudes: The visual nature of some poetic narrative structures." Parergon, 10(2), 71-82.

McGillivray, M (Ed). (2011). Old English reader. Ontario: Broadview.

Niles, J. D. (2006). Old English enigmatic poems and the play of the texts. Turnhout: Brepols.

Niles, J. D. (2003). The problem of the ending of the Wife's Lament. Speculum, 78(4), 1107-1150.

Stewart, A. H. (1975). Old English riddle 47 as stylistic parody. Papers on Language and Literature: A Journal for Scholars and Critics of Language and Literature, 11, 227-241.

Straus, B. R. (1981). Women's words as weapons: Speech as action in the wife's lament. Texas Studies in Literature and Language, 23(2), 268-285.

Williamson, C. (1977). The old English riddles of the Exeter book. Chapel Hill: University of North Carolina Press 